\title{
Tekijyydestä sopiminen vähentää väärinkäsityksiä
}

\author{
Anna-Sofia Ruth \\ Tampereen yliopisto \\ anna.ruth@uta.fi \\ https://orcid.org/0000-0003-0662-4415
}

Who is an author? What does authorship mean? The Finnish Advisory Board on Research Integrity has published a recommendation for agreeing upon the authorship of scientific publications. The recommendation suggests that in order to avoid later complications, the principles of authorship should be discussed and agreed upon in writing prior to publication. ${ }^{1}$

Asiasanat: julkaisutoiminta; tekijyys; tutkimusaineisto; tutkimusetiikka; tutkimusprojektit; tutkimustyö

Tieteelliset julkaisut ovat tärkeitä tutkijan urakehityksen kannalta. Julkaisutietoja kerätään ja tilastoidaan, julkaisujen viittauskertymiä lasketaan ja niiden medianäkyvyyttä seurataan. Samalla yhteisjulkaisujen osuus ja kirjoittajien lukumäärä per artikkeli ovat lisääntyneet jatkuvasti (Brand, Allen, Altman, Hlava, \& Scott, 2015). Ei siis ole ihme, että julkaisujen tekijyydestä syntyy yhä useammin kiistaa (ks. myös Manderbacka, 2015; Weckman, 2016). Riidan aiheena voi olla esimerkiksi se, että jonkun työhön osallistuneen henkilön nimi on jätetty pois julkaisun kirjoittajaluettelosta tai nimien esitysjärjestys ei tyydytä kaikkia kirjoittajia.

1 Osia artikkelista on julkaistu Tampereen yliopiston Kirjastoikkuna -blogissa 13.2.2018. http://blogs.uta.fi/kirjasto/2018/02/13/blogissa-kuka-on-julkaisun-tekija/ 
Tutkimuseettinen neuvottelukunta (TENK) julkaisi tammikuussa Suosituksen tieteellisten julkaisujen tekijyydestä sopimiseksi. Suosituksessa esitetään, että tekijyyden periaatteista keskusteltaisiin ja sovittaisiin mielellään kirjallisesti jo ennen julkaisemista, jolloin vältyttäisiin hankalilta jälkipuinneilta (TENK, 2018). Suositus sisältää myös käytännön apuvälineitä tekijyyksien määrittelyyn.

\section{Mitä tekijyys tarkoittaa?}

Tyypilliset tekijämäärät julkaisua kohti sekä tekijöiden ilmoittamisjärjestys vaihtelevat tieteenaloittain. Siinä missä moni humanisti kirjoittaa monografiansa yksin, saattaa fysiikan tutkimusartikkelin tekijäluettelo sisältää satoja tai jopa tuhansia nimiä. Joillakin tieteenaloilla kirjoittajat luetellaan aakkosjärjestyksessä, mutta useimmiten ensimmäiseksi mainittu kirjoittaja on vastuussa suurimmasta työmäärästä.

TENKin suosituksessa ei määritelläkään tarkasti, kenet tulee mainita tekijäluettelossa ja missä järjestyksessä. Kullakin tieteenalalla voidaan soveltaa ohjeistusta vakiintuneiden käytänteiden mukaisesti. Suosituksessa tekijällä tarkoitetaan henkilöä, joka on osallistunut tieteellisen julkaisun luomiseen niin merkittävällä panoksella, että hänet tulee mainita tekijäluettelossa. Tekijää pidetään usein synonyymina kirjoittajalle, mutta myös tutkimuksen ideointi ja suunnittelu, tutkimusaineiston tuottaminen ja analyysi, tutkimusmateriaalien tai menetelmien kehittäminen, kokoomateoksen toimittaminen tai tutkimusta havainnollistavien kuvien laatiminen ovat sellaista kontribuutiota, jonka merkitsemisestä julkaisuun tulee sopia. Tekijyys ei määräydy työsuhteen, vaan ainoastaan tieteellisen panoksen perusteella. Esimerkiksi opiskelijalla ja työsuhteessa olevalla tutkijalla on siis yhtäläinen oikeus tulla mainituiksi tekijöinä. (TENK, 2018.)

Kansainvälisesti kenties tunnetuimman tekijyyden määritelmän on laatinut International Committee of Medical Journal Editors (ICMJE). Määritelmän mukaan tekijäksi merkitään henkilö, joka on:

- osallistunut merkittävällä panoksella tutkimuksen ideointiin ja suunnitteluun, aineiston keräämiseen tai aineiston analysoimiseen ja tulkintaan JA

- osallistunut julkaisun luonnostelemiseen tai sen kriittiseen tarkistamiseen siten, että on panoksellaan merkittävästi vaikuttanut sen sisältöön JA

- osallistunut lopullisen julkaistavan version hyväksymiseen JA 
- ottanut vastuun työn jokaisesta vaiheesta sekä varmistanut, että hyvää tieteellistä käytäntöä on noudatettu työn kaikissa vaiheissa. (ICMJE, 2018.) ${ }^{2}$

Hyvään tieteelliseen käytäntöön ei kuulu haamukirjoittajien tai lahjakirjoittajien käyttö. Haamukirjoittaja on henkilö, joka on osallistunut merkittävällä tavalla tutkimukseen, mutta jonka nimeä ei mainita kirjoittajaluettelossa. Lahjakirjoittaja puolestaan on henkilö, joka ei ole todella osallistunut tutkimuksen tekoon, mutta jonka nimi silti mainitaan kirjoittajaluettelossa velvollisuudentunnosta tai julkaisun näkyvyyden ja prestiisin nostamiseksi. (TENK, 2018.)

Yksi tapa hahmottaa tekijyyttä on CRediT-luokittelu (Contributor Roles Taxonomy), jossa määritellään erilaisia tutkimustuotoksen luomisen mahdollistavia rooleja ja osallistumisen tasoja (Brand ym., 2015; CASRAI, 2015). Eräät kansainväliset tiedekustantajat ovat jo ottaneet luokituksen käyttöönsä.

\section{Tekijyys ei ole sama kuin tekijänoikeus}

Tekijällä on siis oikeus tulla tunnustetuksi teoksen luojana eikä tuota oikeutta voi poistaa tai siirtää. Tekijänoikeuteen kuuluvat taloudelliset oikeudet sen sijaan voi luovuttaa sopimuksella osittain tai kokonaan. Jos tekijä tai tekijät ovat luovuttaneet kaikki taloudelliset oikeutensa esimerkiksi kustantajalleen tai työnantajalleen, oikeuksien haltijalla on yksinoikeus päättää teoksen myymisestä ja levittämisestä yleisölle. (FINLEX, ei pvm.)

Niin tekijyydestä kuin tekijänoikeuksista sopiminen kirjallisesti ennen julkaisemista vähentää lisäselvitysten tarvetta siinä vaiheessa, kun ollaan esimerkiksi julkaisemassa artikkeliväitöskirjaa, rinnakkaistallentamassa tieteellistä artikkelia julkaisuarkistoon tai suunnittelemassa loppuunmyydyn teoksen uudelleenjulkaisua.

\section{Tutkijan työ on muutakin kuin julkaisujen kirjoittamista}

Sopimusten puuttumisen ja huolimattomuuden ohella kova kilpailu voi johtaa hyvän tieteellisen käytännön rajojen venyttämiseen (mm. Anderson, Ronning, Vries, \& Martinson, 2007). Mikäli tutkijoiden rekrytoinnissa ja palkitsemisessa painotetaan voimakkaasti julkaisuja, voi houkutus julkaisuluettelon paisutteluun kasvaa. Tutkimuseettinen neuvottelukunta on laatinut yhdessä Suomen yliopistot UNIFI ry:n, Ammattikorkeakoulujen rehtorineuvosto Arene ry:n ja 
Suomen Akatemian kanssa myös tutkijan ansioluettelomallin, jota toivottavasti hyödynnetään mahdollisimman laajasti.

TENKin ansioluettelomallissa esitettyjä meriittejä ovat esimerkiksi tutkimusrahoituksen hankinta, tutkimustyön ohjaus- ja johtamiskokemus, opetuskokemus, myönnetyt palkinnot ja huomionosoitukset, väitöskirjan esitarkastajana tai vastaväittäjänä toimiminen, jäsenyys kansallisessa tai kansainvälisessä asiantuntija-, arviointi- tai ohjausryhmässä, tieteellisten julkaisukanavien toimituskuntien jäsenyydet sekä toimittajan tai päätoimittajan tehtävät, tieteellisten aikakauslehtien vertaisarvioijana toimiminen, tutkimustyön tieteellinen ja yhteiskunnallinen vaikuttavuus sekä yhteiskunnalliset luottamustehtävät ja ansiot. (TENK, 2013.)

\section{Lähteet}

Anderson, M. S., Ronning, E. A., Vries, R. D., \& Martinson, B. C. (2007). The perverse effects of competition on scientists' work and relationships. Science and Engineering Ethics, 13(4), 437-461. https://doi.org/10.1007/s11948-007-9042-5

Brand, A., Allen, L., Altman, M., Hlava, M., \& Scott, J. (2015). Beyond authorship: attribution, contribution, collaboration, and credit. Learned Publishing, 28(2), 151-155. https://doi.org/ $10.1087 / 20150211$

CASRAI. (2015). Contributor roles - CASRAI dictionary. http://dictionary.casrai.org/ Contributor_Roles (luettu 4.3.2018)

FINLEX. (ei pvm.). FINLEX - Tekijänoikeuslaki 404/1961. https://www.finlex.fi/fi/laki/ ajantasa/1961/19610404 (luettu 4.3.2018)

ICMJE. (2018). ICMJE recommendations. Defining the role of authors and contributors. http://www.icmje.org/recommendations/browse/roles-and-responsibilities/definingthe-role-of-authors-and-contributors.html (luettu 4.3.2018)

Manderbacka, K. (2015). Tekijyys tieteessä. Tutkimuseettisen toimikunnan (TENK) syysseminaari Helsingissä 25.11.2015. Sosiaalilääketieteellinen aikakauslehti, 53(2), 147-150. https: //journal.fi/sla/article/view/56926 (luettu 4.3.2018)

TENK. (2013). Tutkijan ansioluettelomalli. http://www.tenk.fi/sites/tenk.fi/files/tutkijan_ ansioluettelomalli_260613.pdf (luettu 4.3.2018)

TENK. (2018). Tieteellisten julkaisujen tekijyydestä sopiminen: tutkimuseettisen neuvottelukunnan suositus 2018. http://WWw.tenk.fi/sites/tenk.fi/files/TENK_suositus_tekijyys.pdf (luettu 4.3.2018)

Weckman, M. (2016). Tekijyyteen liittyvät tutkimuseettiset ongelmat kasvussa. Acatiimi, (5), 26. http://www.acatiimi.fi/5_2016/05_16_15.php (luettu 4.3.2018) 